\title{
Pattern of Aerobic bacterial infections in Nephrotic children
}

\author{
Saima Easin'1, Naima Muazzam², S.M. Shamsuzzaman³, Moushumi Sarker ${ }^{3}$, Akhtaruzzaman Chowdhury ${ }^{3}$ \\ ${ }^{1}$ Department of Microbiology, NICRH, Mohakhali, Dhaka. ²Department of Microbiology (former), Dhaka Medical College, Dhaka. \\ 3Department of Microbiology, Dhaka medical College, Dhaka.
}

\begin{abstract}
A bstract
100 nephrotic children were studied in the Microbiology Department of Dhaka Medical College, Dhaka, from J anuary to December/ 2004. The mean age was 5.4 years (range 1-15 yrs.), 68 were male and the rest 32 were female All children were diagnosed case of nephrotic syndrome having International Study of Kidney Diseases in Children (ISKDC) criteria with normal renal functions. The patients were monitored dinically presented with any infections as a complication of nephrotic syndrome and investigations were carried out accordingly. 59 patients were found to have various types of infections. Urinary tract infection (UTI) was the commonest and seen in 50 patients. Peritonitis and cellulitis were present in two patients each. The most common isolated organism was E.coli and Pseudomonas in urine. E.coli was mostly susceptible to Ciprofloxacin but resistant to Ceftriaxone. Pseudomonas was mostly resistant to ceftriaxone but susceptible to imipenem.
\end{abstract}

K ey words: Nephrotic syndrome, Infection, Resistance.

\section{Introduction:}

Nephrotic Syndrome is a common renal disease, which is characterized by massive proteinuria, hypoalbuminaemia, hyperlipidaemia and generalized oedema. ${ }^{1}$ According to International Study of Kidney Diseases in Children (ISKDC), nephrotic proteinuria is defined as urinary protein excretion exceeds $2.5 \mathrm{gm}$ in 24 hours ( $>1 \mathrm{gm} / \mathrm{m}^{2} / 24$ hours) and serum albumin drops below 2.5 gm/dl. ${ }^{2}$ In developing countries, infection is an important complication of nephrotic children resulting significant morbidity and may also be responsible for a poor response to steroid therapy or induce relapse in children who has al ready attained remission. ${ }^{3}$

The incidence of infections in nephrotic children is high. Physical findings may be minimal due to extensive use of corticosteroids with or without use of other

\section{Correspondence:}

Dr. Saima Easin

Asstt. Professor

Department of Microbiology

NICRH, Mohakhali, Dhaka.

Tel: 01552-396711 immunosuppressive agents in the treatment of Nephrotic Syndrome. Bacterial infections in nephrotic children comprise urinary tract infection (UTI), pneumonia, septicemia, pulmonary tuberculosis (PTB), skin infection, peritonitis etc. Recent reports suggest that UTI is the predominant infection in nephrotic children. So, urine should be cultured in following circumstances, (1) on admission, as a screening investigation before initiation of steroid therapy, (2) In all children with steroid non-response with 4 weeks course of steroids, (3) In patients in remission with symptoms suggestive of UTI such as fever, dysuria or hematuria; (4) In nephrotic children with relapse ${ }^{4}$ Previously gram positive as well as gram negative organi sms were responsible for various infections in nephrotic children. Subsequently with corticosteroid treatment and overuse of antibiotics, Gram negative organisms were found predominantly with their changing antimicrobial susceptibility pattem. ${ }^{5}$

\section{M aterials and methods:}

Place and duration of the Study: This cross sectional study was carried out in the Department of Microbiology, Dhaka Medical College (DMC), Dhaka, Bangladesh, for a period of oneyear. 
Study population, Inclusion criteria: Total 100 clinically diagnosed nephrotic syndrome patients (based on general ized oedema, proteinuria, detected by heat coagulation test, oliguria or scanty micturition) were included. Samples were collected from patients admitted in the Pediatric department of Dhaka Medical College Hospital (DMCH), Dhaka, National Institute of Kidney diseases and urology (NIKDU), Dhaka and Pediatric Nephrology department of Bangobondhu Sheikh Mujib Medical University (BSMMU), Dhaka.

Methodology: About $20 \mathrm{ml}$ of mid-stream urine was asceptically collected from all patients and transported to the laboratory as early as possi ble. By using standard loop (4mm) method, a fixed known volume $(0.004 \mathrm{ml})$ of urine was inoculated into Blood and MacConkey agar media and aerobically incubated at $37^{\circ} \mathrm{C}$ for 24 hours. If growth occured, the number of colony were counted to cal culate the number of viable bacteria in urine. A count of $1 \times 10^{5}$ or more bacteria/ml of urine was taken as clinically significant. Two $\mathrm{ml}$ of blood was asceptically collected from eight suspected septicemicnephrotic patients and were inoculated into $20 \mathrm{ml}$ of Tripticase Soya broth (TSB) and aerobically incubated at $37^{\circ} \mathrm{C}$. Among 100 nephrotic cases, eight patients were tested for cellulitis/abscess and pus or cellular exudates were asceptically collected from infected sites by using sterile cotton-wool swab and inoculated into Blood and MacConkey agar media and aerobically incubated at $37^{\circ} \mathrm{C}$ for 24 hours. 2$3 \mathrm{ml}$ of peritoneal fluid was collected asceptically from 4 asciticnephrotic cases and were inoculated into Blood and MacConkey agar media and aerobically incubated at $37^{\circ} \mathrm{C}$ for 24 hours. The organisms were isolated by using various chemical tests (fermentation reaction in KIA media, motility test in MIU media and citrate utilization test). ${ }^{6}$ The bacterial isolates were tested for antimicrobial susceptibility test by agar disc diffusion method against different antimicrobial agents like ampicillin (AMP), gentamycin (CN), cotrimoxazole (STX), cephalexin (CEF), ciprofloxacin (CIP), ceftriaxone (CRO), nalidixic acid (NA), nitrofurantoin (F), carbenicillin (CAR), ceftazidime (CAZ), imipenem (IMP) etc. The diameter of complete zone of inhibition around each disc was measured in $\mathrm{mm}^{7}$

\section{Results:}

In this study of 100 nephrotic children, 77 cases were up to 6 years of age, of them $48(81.4 \%)$ were culture positive (Table-l). The rest 23 cases were between six to fifteen years of age, of which $11(18.6 \%)$ cases were culture positive $(\mathrm{p}<0.001)$. The ratio of male and female was 2:1. Among 59 culture positive cases, male children were significantly more than female ( $p \varangle 0.001$ ) (Table II). Out of 59 culture positive patients, UTI was the commonest infection (84.7\%). Among the aetiological agents, 37 (74\%) patients were found to have E. coli in their urine samples. Pseudomonas, Klebsiella, Proteus were found in 7 (14\%), 4 (8\%) and 2 (4\%) patients respectively (Table-III). Most of the isolated organisms were susceptible to ciprofloxacin except Pseudomonas, which was $100 \%$ resistant. $65 \%$ E.coli was susceptible to ciprofloxacin, $35 \%$ to nitrofurantoin, $30 \%$ to nalidixic acid and $25 \%$ of E.coli were susceptible to gentamycin. 100\% E.coli were resistant to ceftazidime and carbenicillin whereas 30\% and $20 \%$ Pseudomonas was sensitive to ceftazidime and carbenicillin respectively. 100\% Klebsiella and $100 \%$ Proteus were resistant to ampicillin, carbenicillin, ceftazidime, cephalexine, cotrimoxazole but $100 \%$ were susceptible to ciprofloxacin. $100 \%$ Pseudomonas were resistant to ciprofloxacin and ceftriaxone whereas $80 \%$ of them were susceptible to only imipenem Among 88 nephrotic patients who were diagnosed as initial cases, 50 (56.81\%) were culture positive and 9 (75\%) of the 12 cases who developed relapse were culture positive $(p<0.01)$.

Table-I: Age distribution of the nephrotic syndrome cases $(n=100)$

\begin{tabular}{lccc}
\hline Age (years) & $\begin{array}{c}\text { Culture positive } \\
\text { cases }(n=59) \\
\text { No }(\%)\end{array}$ & $\begin{array}{c}\text { Culture negative } \\
\text { cases }(n=41) \\
\text { No }(\%)\end{array}$ & Mean age \\
\hline$\leq 6$ & $48(81.4)$ & $29(70.47)$ & 5.4 \\
$>6-15$ & $11(18.6)$ & $12(29.53)$ & \\
Total $(n=100)$ & $59(100)$ & $41(100)$ & \\
\hline
\end{tabular}

$P$ value ( $Z$ test): $P<0.001$

Table-II: Sex distribution of the nephrotic syndrome cases ( $n=100)$

\begin{tabular}{lccc}
\hline Sex & $\mathrm{n}=100$ & $\begin{array}{c}\text { Culture positive cases } \\
(\mathrm{n}=59) \text { No }(\%)\end{array}$ & $\begin{array}{c}\text { Culturenegativecases } \\
(\mathrm{n}=41) \text { No }(\%)\end{array}$ \\
\hline Male & 68 & $43(72.9)$ & $25(61.0)$ \\
Female & 32 & $16(27.1)$ & $16(39.0)$ \\
Total & 100 & $59(100)$ & $41(100)$ \\
\hline
\end{tabular}

$P$ value ( $Z$ test): $P \varangle 0.001$

Table-III: Organisms isolated from different samples of culture positive nephrotic cases $(n=59)$.

\begin{tabular}{|c|c|c|c|c|c|c|}
\hline \multirow{2}{*}{$\begin{array}{l}\text { Types of } \\
\text { infection }\end{array}$} & \multirow{2}{*}{$\begin{array}{l}\text { Material } \\
\text { used for } \\
\text { culture }\end{array}$} & \multirow{2}{*}{$\mathrm{n}$} & \multicolumn{4}{|c|}{ Organismisolated } \\
\hline & & & $\begin{array}{l}\text { E.coli } \\
\text { n(\%) }\end{array}$ & $\begin{array}{c}\text { Pseudomonas } \\
n(\%)\end{array}$ & $\begin{array}{c}\text { Klebsiella } \\
\text { n (\%) }\end{array}$ & $\begin{array}{l}\text { Proteus } \\
\mathrm{n}(\%)\end{array}$ \\
\hline UTI & Urine & 50 & $37(74)$ & $7(14)$ & $4(8.0)$ & $2(4.0)$ \\
\hline $\begin{array}{l}\text { Cellulitis/skin } \\
\text { infection }\end{array}$ & $\begin{array}{l}\text { Pus/cellular } \\
\text { exudates }\end{array}$ & 5 & $1(20)$ & $2(40)$ & $0(00)$ & $2(40)$ \\
\hline Septicemia & Blood & 2 & $1(50)$ & $1(50)$ & $0(00)$ & $0(00)$ \\
\hline Peritonitis & $\begin{array}{l}\text { Peritoneal } \\
\text { fluid }\end{array}$ & 2 & $1(50)$ & $0(00)$ & $1(50)$ & $0(00)$ \\
\hline Total & & 59 & 40 & 10 & 5 & 4 \\
\hline
\end{tabular}




\section{Discussion:}

Nephrotic syndrome is primarily a pediatric disorder, which is characterized by massive proteinuria, hypoal buminaemia, hyperlipidaemia and generalized oedema. Male children are predominantly affected and most commonly appears between 2-6 years of age. In this study of 100 nephrotic cases, 77 cases were up to 6 years of age and 23 cases were between 6 15 years of age. In a study at IPGM\&R, Dhaka, found maximum cases between the age 2-10 years of age ${ }^{8}$ Among 59 culture positive cases, $48(81.40 \%)$ cases were up to six years and the rest 11 (18.6\%) were between > 6-15 years of age ( $p \varangle 0.001$ ). Childhood nephrotic syndrome is common between 2-6 years of age and become more immunodeficient during active disease and become more susceptible to bacterial infections. ${ }^{9}$ There may be a relation that nephrotic children with hypoal buminaemia and lower level of serum Ig $\mathrm{G}$ may predispose to bacterial infection. ${ }^{10}$ In this study, the ratio of male and female was 2:1. Among 59 culture positive cases, male children were significantly more than female ( $p$ $\varangle 0.001$ ). The ratio between male and female were 2.5:1 and 3:1 reported in different studies. ${ }^{11,4}$ In this study, UTI was the commonest infection with a preval ence of $50 \%$. It was found that UTI was the commonest infection among nephrotic children. ${ }^{12,8}$ Among the isolated organisms, $74 \%$ were E. coli in their urine samples followed by Pseudomonas, Klebsiella, Proteus, were found in $14 \%, 8 \%$ and $4 \%$ patients respectively. Cellulitis was the second common (62.5\%) which was similar with the study of Senguttuvan. ${ }^{13}$ In this study, 2 septicaemic and 2 cases were diagnosed as peritonitis. W. Scott reported $13.4 \%$ of nephrotic children presenting with the type of acute abdominal emergency. ${ }^{14}$ Fowler (1957) established that the majority of cases were caused by gram positive organisms particularly Pneumococci and Haemolytic streptococci. In this study, E.coli and klebsiella were found in one patient each. ${ }^{15}$ Previously grampositive organisms were responsible for peritonotis. Subsequently with corticosteroid treatment and overuse of antibiotics, gram-negative organisms have been found predominenetly with their changing antimicrobial susceptibility pattern. In the present study of nephrotic syndrome, a majority of patients were initially attended by general practitioners or at other hospitals and had received symptomatic treatment and antibiotics resulting low bacterial culture positivity. As a result, occult infections were found to be responsible for non-response to steroid therapy, resulting hospitalization of the patients. Infected nephrotic syndrome cases had significantly delayed protein free urine despite adequate treatment. Wilfert had similar observations. ${ }^{16}$

The isolated gram-negative organisms of this study were tested against different antimicrobial discs according to the samples and organisms. They were susceptible to ciprofloxacin in most of the cases except Pseudomonas, which was $100 \%$ resistant. E.coliwere mostly susceptible to ciprofloxacin, nitrofurantoin, nalidixic acid and gentamycin. Only $15 \%$ E.coli were susceptible to ceftriaxone and cotrimoxazole. $100 \%$ E.coli were resistant to ceftazidime and carbenicillin whereas Pseudomonas was $30 \%$ and $20 \%$ sensitive to them respectively. $100 \%$ Klebsiella and100\% Proteus were resistant to ampicillin, carbenicillin, ceftazidime, cephalexine, cotrimoxazole but $100 \%$ were susceptible to ciprofloxacin. $100 \%$ Pseudomonaswere resistant to ciprofloxacin and ceftriaxone The antibiogram of this study was dissimilar to the previous studies in which third generation cephal osporin therapy covered most of the gram-negative organisms. 17,18 UTI in nephrotic patients is increasing worldwide with the prevalence of antimicrobial resistance In this study, as all the samples were collected from admitted patients and gram negative bacilli were the most common causes of nosocomial infection, possess multiple modes of antibiotic resistance and were highly efficient in horizontally transferring them between species. The emergence and spread of resistance can be reduced by appropriate \& careful use of antimicrobial agents. ${ }^{19}$

\section{Conclusion:}

Infection is an important complication of nephrotic syndrome patients as observed in 59 patients out of total 100 patients. UTI was the commonest infection followed by cellulitis, peritonitis and septicemia. Infections were caused by Gram negative bacteria, which were mostly resistant to ceftriaxone. Infections remain the chief cause of mortality and considerably morbidity. So prevention and early recognition of infections are crucial in nephrotic syndrome.

\section{REFERENCES:}

1. Behrman RE, KligmanRm, Nelson WE, VaughanVC, editors. Nelson Textbook of Pediatrics. $14^{\text {th }}$ ed. Philadel phia; W.B. Saunders company, 2004: 1341-43.

2. Brodehil J, Nephrotic syndrome in children: Diagnosis and treatment. World Pediatr. Child care 1986: 1: 9-18.

3. Abrass c: Clinical spectrum and complications of nephrotic syndrome. J Clin. Invest Med 45:143. 1997.

4. Gulati S; Kher V; Gupta S; Kali S. Urinary tract infection in nephrotic syndrome. Pediatr infect DisJ 1996 Mar; 15 (3): 237-40.

5. Tapaneya-Olarn-C; .Tapaneya-Olarn-W. Primary peritonitis in childhood nephrotic syndrome: a changing trend in causative organisms. J-Med-Assoc-Thai. 1991 Nov; 74(11): 502-6. 
6. Cheesbrough M. Medical Laboratory Manual for tropical countries. Vol-11.Cambridgeshire: ELBS, 2000:pp-182-8.

7. Bauer AW, Kirby WMM, Sherris. Antibi otic susceptibility testing by a standard single disc method.Am J Clin.Pathol.1996: 45; 493-6.

8. Chowdhury M A, Rahman M E, Hossain M. Pattem of infections in childhood Nephrotic Syndrome, Dhaka shishu (children) Hospital J ournal 1998; 14: 13-17.

9. Behman RE, KligmanRm, In: Nelson WB, Vaughan VC Nelson Textbook of Pediatrics. 14th ed. Philadelphia; W.B. Saunders company, 2004: 1341-43.

10. Andal A, Chellani $H$, Anand N K, Chandra M; Low serum immunoglobulin $\mathrm{G}$--a predictor of frequent relapses in idi opathic nephrotic syndrome. Indian pediatr. 1990 (Oct) ; 27 (10): 1045-9.

11. Moorani KN, Khan KM, Ramzan A. Infections in children with nephrotic syndrome J Coll Physicians Surg Pak. 2003 Jan; 13(6): 337-9.

12. FKeFu. EK-N. Renal disorder in children: A Nigerian study; PediatrNephrol, 1994; J un; 8(13): 383-6.
13. Shenguttuvan P, Ravanan K, Pravu N, Tamilarasi V. Infections encountered in childhood nephrotics in a pediatrics renal unit. An untitled document of 2004.

14. W. Scott, Macdougal, Robert, J Izant, Robert M. Primary peritonitis in infancy and childhood. 1978; 40: 132-135.

15. Fowler R. Primary peritonitis. Aust NZ srg 1957; 26: 204-213.

16. Wilfert CM, Katz CL. Etiology of bacterial sepsis in nephrotic syndrome. Pediatrics 1968 ; 42: 840-43.

17. Tain YL, Lin G, Cher TW. Microbiological spectrum of septicemia and peritonitis in nephrotic children.PediatrNephrol. 1999 Nov; 13(9): 835-7.

18. Liponski I, Cochat P, Gagnadoux MF, Parchoux B, Niaudet P, David L, Broyer M. Bacterial complications of nephrotic syndrome in children. Presse Med. 1995 Jan; 13(1): 19-25.

19. Abdul Rahman Abdullah Kader, A. Kumar, Seivarayan Mahimai Dass; Anti-microbial resistance pattern of Gram-negative bacteria isolated from urine culture at a general hospital. Saudi J Kidney Dis Transplant 2004; 15(2);135-139. 